\title{
BRINE SHRIMP LETHALITY BIOASSAY OF ABRUS PRECATORIUS (LINN) LEAVES AND ROOT EXTRACT
}

\author{
WAKAWA H. Y., FASIHUDDIN B. A. \\ Department of Biochemistry, FSTS/FRST Universiti Malaysia Sarawak, Kuching, 94300 Kota Samarahan \\ Email: ntawa1hen@yahoo.com
}

Received: 05 Sep 2016 Revised and Accepted: 18 Nov 2016

\section{ABSTRACT}

Objective: The present study was conducted to test for in vivo Brine Shrimp Lethality Assay (BSLA) of Abrus precarious leaves and root extracts after successive maceration in four solvents (n-hexane, dichloromethane (DCM) ethyl acetate and methanol) and correlate cytotoxicity results with known pharmacological activities of the plant.

Methods: Cytotoxicity was evaluated in terms of LC $_{50}$ (lethality concentration), 10 nauplii were added into three replicates of each concentration of the plant extracts, and after $24 \mathrm{~h}$ the surviving brine shrimp larvae were counted, and $\mathrm{LC}_{50}$ was assessed.

Results: Potent cytotoxicity was found for both the leaves and root extracts of Abrus precatorius, results showed a concentration dependent increment in mortality rate of the brine shrimp nauplii and the n-hexane and dichloromethane fractions of the root and leaves extracts were more potent against the brine shrimp with $\mathrm{LC}_{50}$ values of $7.870 \mathrm{ppm}$ and $19.135 \mathrm{ppm}(\mu \mathrm{g} / \mathrm{ml})$ respectively, whereas methanol fractions of both the extracts exhibited low potent activity with $\mathrm{LC}_{50}$ values $61.575 \mathrm{ppm}$ and $226.053 \mathrm{ppm}(\mu \mathrm{g} / \mathrm{ml})$ in root and leaves respectively.

Conclusion: The result indicated bioactive components are present in this plant that could be accounted for its pharmacological effects.

Keywords: Insert Brine shrimp, cytotoxicity, extracts, LC50, Abrus precatorius

(C) 2017 The Authors. Published by Innovare Academic Sciences Pvt Ltd. This is an open access article under the CC BY license (http://creativecommons.org/licenses/by/4. 0/]

DOI: http://dx.doi.org/10.22159/ijpps.2017v9i1.15057

\section{INTRODUCTION}

In vivo lethality in a simple zoological organism (brine shrimp) can be used as a convenient monitor for screening and fractionation in the discovery and monitoring of bioactive natural product, it is a general assay and capable of detecting various bioactivity present in crude extracts of medicinal plants [1] and has been used as an indicator for general toxicity and as a guide for the detection of antitumor and pesticidal compounds [2, 3]. Since its introduction by Meyer et al. [3], it is noted as a useful tool for the isolation of bioactive compounds [4-6] and toxic compounds [2, 7] from plant extract, as well as used successfully for the bioassay-guided isolation of active antitumor and cytotoxic agent's trilobacin from the bark of Asimina tribola [2]. The technique is cost-effective and can be mastered easily and require a small amount of sample [1]. It has also been used to prove the presence of anti-tumorous compounds in $C$. bonplandianum [8] and to depict the general trend among plants of the genus Terminalia, which are known to contain cytotoxic compounds like hydrolyzable tannins [9].

Historically, medicinal plants have provided a good source of inspiration for novel therapeutic drugs as plant-derived medicines have made large contributions to the health and well-being of humans. Some traditional medicine involves using crude plant extract which may contain an extensive diversity of molecules often with indefinite biological effects [10], it is therefore obvious that some negative results obtained with the use of local plants as sources of medicine or drugs are basically due to over-dosage and lack of adequate knowledge of other detrimental by-products (poisons) contained in some plants [11] and most of the available information regarding the medicinal potential of these plants are not provided with credible scientific data. Thus, research to determine the efficacy of medicinal plants should be encouraged and documented to reduce the risk of silent complexities that are associated with traditional medicine. A. precatorius (Linn) is a medicinal plant widely used for the treatment of many diseases as well as vegetable and artefacts in many cultures, and it is widely found in Africa, India and many other parts of the world. The leaves are used as a sweetener in foods and certain remedies to treat fevers, cough and cold (use as a decoction) due to its characteristic sweet taste and most time it is casually chewed with the vine sometimes sold as a masticatory in Curacao [12]. It was reported to protect the liver against $\mathrm{CCl}_{4}$ induced liver damage in rats [13] among other uses thus; this work is designed to investigate the cytotoxic activity of $A$. precatorius leaves and root extracts in different solvents (n-hexane, dichloromethane (DCM), ethyl acetate and methanol).

\section{Plant materials and preparation of extract}

Fresh leaves and roots of $A$. precatorius were used for the preparation of the crude extract, they were collected from an uncultivated farmland in Girei LGA of Adamawa State-Nigeria and authenticated in the plant science department of the Modibbo Adama University of Technology, Yola and were given a voucher specimen number WH/APL015/06 and WH/APL015/07, they were dried under room temperature.

The freshly dried leaves and the root of $A$. precatorius were grounded into powdered forms using laboratory grinder machine (FGR-350, Quest Scientific), serial extraction was done using four different solvent systems (n-hexane, dichloromethane (J. T. Baker), ethyl acetate and methanol (Merck KGaA). $100 \mathrm{~g}$ of the powdered samples was weighed into an Erlenmeyer flask and each solvent (three times the weight of the extracts) was added, the solutions were covered and shaken at a time interval of an hour and then allow to stand for $7 \mathrm{~d}$ at room temperature. The mixtures were then filtered using Whatman filter paper No.4 and the solvent was evaporated using a rotary evaporator (Heidolph Laborato 400) under reduced pressure below $60^{\circ} \mathrm{C}$.

\section{Hatching of brine shrimp}

$1.5 \mathrm{~g}$ of Artemia salina cysts (Sanders Great Salt Lake, Brine Shrimp Company U. S. A.) was aerated in $1 \mathrm{~L}$ capacity glass container containing filtered seawater (collected from Damai beach in Kuching-Sarawak). Air pump was fitted to the water to ensure complete aeration of the cysts after $48 \mathrm{~h}$ of incubation at room temperature $\left(27-29{ }^{\circ} \mathrm{C}\right)$ under continuous illumination of 
fluorescence lamp newly hatched free-swimming nauplii were harvested from the bottom of the glass container. The freshly hatched free-swimming nauplii were used for the bioassay.

\section{Preparation of test samples}

An alternative dilution procedure developed by McLaughlin et al. [14] was adopted in the preparation of different dilution of the plant extracts, $4 \mathrm{mg}$ of each extract was dissolved in $200 \mu \mathrm{l}$ of DMSO (RCI Labscan limited) and a lower series of chosen concentration was prepared by serial dilution with DMSO. The assay system was prepared with $5 \mathrm{ml}$ of filtered seawater containing chosen concentration of extract and $1 \%$ yeast extract (for feeding) in a premarked 6-well microplate and 10 brine shrimps were carefully taken with a micropipette and introduced into each microplate, this was done in triplicates making a total of 30 brine shrimps per concentration. Filtered seawater was added to DMSO in a set of 3 pre-marked 6-well microplate and 10 brine shrimps were carefully taken with a micropipette and introduced into each microplate, this was used as the control groups.

If the brine shrimp in these microplates shows a rapid mortality rate, then the test is considered invalid as the nauplii might have died due to some reasons other than the cytotoxicity of the extracts. The setup was allowed to remain for $24 \mathrm{~h}$ under constant illumination of fluorescent and number of survived nauplii were counted with a hand lens, from the data the average death of the brine shrimp at different concentrations of the extract and the $\mathrm{LC}_{50}$ of the plant was calculated using probit regression by statistical software SPSS 22 and the result was expressed as mean+SEM at the $95 \%$ level of confidence $(p<0.05)$.

Table 1: Average death of Artemia salina brines shrimp at different concentrations of the root extract of $A$. precatorius $\mathrm{L}$

\begin{tabular}{|c|c|c|c|c|c|c|c|}
\hline \multirow[t]{2}{*}{ Solvent system } & \multicolumn{6}{|c|}{ Average death of Artemia salina brines shrimp concentration ppm $(\mu \mathrm{g} / \mathrm{ml})$} & \multirow[t]{2}{*}{$\mathrm{LC}_{50}(\mathrm{mg} / \mu \mathrm{l})$} \\
\hline & Control & 1 & 5 & 10 & 50 & 100 & \\
\hline hexane & 0 & $3+0.57$ & $4+0.57$ & $5+0.57$ & $7+0.57$ & $10+0.00$ & 7.870 \\
\hline DCM & 0 & $2+0.57$ & $3+0.57$ & $4+0.57$ & $5+0.57$ & $10+0.00$ & 14.951 \\
\hline ethyl acetate & 0 & $3+0.57$ & $5+0.57$ & $6+0.57$ & $7+0.57$ & $10+0.00$ & 19.135 \\
\hline methanol & 0 & $3+0.57$ & $3+0.57$ & $5+0.57$ & $5+0.57$ & $5+1.16$ & 61.575 \\
\hline
\end{tabular}

The result is mean+SD. $\mathrm{N}=30$, table 1 . Above show the average death and $\mathrm{LC}_{50}$ of Artemia salina brine shrimp at different concentration of the root extract of $A$. precatorius $\mathrm{L}$.

Table 2: Average death of Artemia salina brines shrimp at different concentrations of the leaves extract of a. precatorius $\mathrm{L}$

\begin{tabular}{|c|c|c|c|c|c|c|c|}
\hline \multirow[t]{2}{*}{ Solvent system } & \multicolumn{6}{|c|}{ Average death of Artemia salina brines shrimp, concentration ppm $(\mu \mathrm{g} / \mathrm{ml})$} & \multirow[t]{2}{*}{$\mathrm{LC}_{50}(\mathrm{mg} / \mu \mathrm{l})$} \\
\hline & Control & 1 & 5 & 10 & 50 & 100 & \\
\hline hexane & 0 & $3+0.57$ & $3+0.57$ & $4+0.57$ & $5+0.57$ & $7+0.57$ & 32.627 \\
\hline DCM & 0 & $3+0.57$ & $4+0.57$ & $5+0.57$ & $6+0.57$ & $6+0.00$ & 19.135 \\
\hline ethyl acetate & 0 & $2+0.57$ & $3+0.57$ & $4+0.57$ & $5+0.57$ & $6+0.00$ & 61.575 \\
\hline methanol & 0 & 0 & $1+0.57$ & $2+0.57$ & $3+0.57$ & $3+0.57$ & 226.053 \\
\hline
\end{tabular}

The result is mean+SD. $\mathrm{N}=30$, table 2. Above show the average death and $\mathrm{LC}_{50}$ of Artemia salina brine shrimp at different concentration of the leaves extract of $A$. precatorius $\mathrm{L}$.

\section{Significance of brine shrimp lethality assay of the plant}

The evolution of the toxic action of plant extracts is indispensable to consider a treatment safe, it enables the definition of the intrinsic toxicity of the plant, and the effects of acute overdose [15], a cheap and general bioassay that appears capable of detecting a spectrum of bioactivity present in crude extract is the brine shrimp lethality test. The lethality of the test sample in a simple zoological organism like the brine shrimp (Artemia salina) has been utilised by many researchers and has proven to be a useful tool in screening various chemical compounds found in various bioactivities. In this study, it was observed $n$-hexane fraction of the root extract exhibited the highest brine shrimp cytotoxic activity with $\mathrm{LC}_{50}$ value of 7.870 $\mu \mathrm{g} / \mathrm{ml}$ followed by a dichloromethane extract with $\mathrm{LC}_{50}$ value of $14.951 \mathrm{ppm}(\mu \mathrm{g} / \mathrm{ml})$ and the methanol fraction extract exhibited the lowest brine shrimp cytotoxic activity with $\mathrm{LC}_{50}$ value of 61.575 $\mathrm{ppm}(\mu \mathrm{g} / \mathrm{ml})$ (table 1). The result of the leaf extract revealed dichloromethane fraction exhibited $\mathrm{LC}_{50}$ value of $19.135 \mathrm{ppm}$ $(\mu \mathrm{g} / \mathrm{ml})$, and methanol fraction of the extract exhibited $\mathrm{LC}_{50}$ value of $226.053 \mathrm{ppm}(\mu \mathrm{g} / \mathrm{ml})$ as the highest and lowest brine shrimp lethality activities respectively (table 2). There was an observed concentration-dependent increment in the mortality rate of the brine shrimp; this is considered an indication of proof the cytotoxic effect of the plant extracts reported to have antiseptic activity [16], antimicrobial activity [17] and antifungal activity [18] among others. The result of the present study, specifically the brine shrimp lethality of the leaf extract is congruent with the previous findings of Adedepo et al. [19] who reported the toxic effect of the aqueous extract of the leaves of $A$. precatorius in rats.

The leaves and root extracts of $A$. precatorius exhibited a concentration-dependent cytotoxic activity in brine shrimp and is considered containing active or potent components, brine shrimp lethality assay is inadequate in determining the mechanism of action of the bioactive substances in the plant, but it is useful in providing a preliminary screen that can be supported by a more specific bioassay, once the active compound has been isolated. Thus, some useful drugs of therapeutic importance may develop out of the research work.

\section{ACKNOWLEDGEMENT}

The authors are grateful for the grant provided for this research work. FUNDING

This research was supported by grant no F07(DPP19)/1187/2014(19)

\section{CONFLICT OF INTERESTS}

Declared none

\section{REFERENCES}

1. Ghisalberti EL. Detection and isolation of bioactive neutral products. In S. M. Colgate and molyneux editor. Bioactive natural products: detection, isolation and structure. Boca Raton: CRS Press; 1993. p. 15.

2. Zhao G, Hui Y, Rupprecht JK, McLaughlin JL, Wood KV. Additional bioactive compounds and Trilobacin, a novel highly cytotoxic acetogenin from the bark of Asimina tribola. J Nat Prod 1992;55:347-56.

3. Meyer BN, Ferrigni NR, Putna JE, Jacobsen LB, Nichols DE, McLaughlin JL. Brine shrimp: a convenient general bioassay for active plant constituents. Plant Med 1991;45:31-4.

4. Kaniz FU, Samina M, Gulshanara B, Kaiser H. Comparative brine shrimp lethality bioassay of different plants of Bauhinia pueprea L. J Pharm Sci Res 2013;5:190-2. 
5. Lilybeth FO, Olga MN. Brine shrimp lethality assay of the ethanolic extract of three selected species of medicinal plants from Iligan City, Philippines. Int Res J Biosci 2013;2:74-7.

6. Sirito P, Pinyupa P, Nasit P, Siriluk R, Onrudee M. Brine shrimp lethality activity of thai medicinal plants in the family Meliaceae. Naresuan University J 2004;12:13-8.

7. Nguta JM, Mbaria JM, Gakuya DW, Gathumbi PK, Kabasa JD, Kaima SG. Evaluation of acute toxicity of crude extracts from Kenya biodiversity using brime shrimp, Artemia salina L. (Artemiidae). Open Conference Proceedings J 2013;3:30-4.

8. Ghosh A, Chatterjee P. Brine shrimp cytotoxic activity of $50 \%$ alcoholic extract of Croton bonplandianum baill. Asian J Pharm Clin Res 2013;6 Suppl 3:40-1.

9. Zakaria HM, Mainen JM, Pax JM, Modest CK, Ramadhani SON. Antimicrobial activity and brine shrimp toxicity of extracts of Terminalia brownii roots and stem. BMC Complementary Altern Med 2007;7:9-15.

10. Konan NA, Bacchr EM, Linconpan N, Varela SD, Varenda EA Acute, sub-acute toxicity and genotoxic effect of hydroethanolic extract of the cashew (Anacadium occidentali L.) J Ethnopharmol 2007;110:30-8.

11. Nwachukwu CU, Ume NC, Obusi MN, Nzewuihe GU, Onyiroiha CU. The qualitative uses of some medicinal plants in Ikeduru L. G. A. of Imo State, Nigeria. New York Sci J 2010;3 Suppl 11;129-34.

12. Morton JF. Atlas of medicinal plants of middle America: The Bahamas to Yucatan. Springfield, Illinois: Charles C Thomas 1981;46:241-56.
13. Wakawa HY, Musa H. Protective effect of Erythrina senegalensis (DC) leaf extracts on $\mathrm{CCl} 4$ induced liver damage in rats. Asian J Biol Sci 2013;6:234-8.

14. McLaughlin JL, Rogers LL. The use of the biological assay to evaluate botanicals. Drug Info J 1998;32:513-24.

15. Padjama R, Arun PC, Prashanth D, Deepak M, Amit A, Anajna M. Brine shrimp lethality bioassay of Indian medicinal plants. Fitoterapia 2002;73:508-10.

16. Abhilasha S, Kuntal K. Analysis of phytochemical constituents and pharmacological properties of Abrus precatorius L. Int J Pharmacol Biol Sci 2013;4:91-6.

17. Adelowotan O, Aibinu I, Aednipekun E, Odugbemi T. The in vitro antimicrobial activity of Abrus Precatorius (L) fabaceae extract on some clinical pathogens. Nigerian Postgrad Med J 2008;15:32-7.

18. Prashith Kekuda TR, Vinayaka KS, Soumya KV, Ashwini SK, Kiran R. Antibacterial and antifungal activity of methanolic extract of Abrus pulchellus wall and Abrus precatorius Linn-a comparative study. Int J Toxicol Pharmacol Res 2010;2:26-9.

19. Adedapo AA, Omoloye OA, Ohore OG. Studies on the toxicity of an aqueous extract of the leaves of Abrus precatorius in rats. Onderstepoort J Vet Res 2007;74:31-6.

\section{How to cite this article}

- Wakawa HY, Fasihuddin BA. Brine shrimp lethality bioassay of Abrus precatorius (Linn) leaves and root extract. Int J Pharm Pharm Sci 2017;9(1):179-181. 